\title{
Retrospective Analysis of Toxicity Profiles of Two Platinum-Based Salvage Regimens in Relapsed/ Refractory Lymphoma: DHAP versus ESHAP
}

\author{
Ozan SALIM ${ }^{1}$, Tayfur TOPTAS ${ }^{2}$, Derya K. SALIM ${ }^{3}$, Orhan K. YUCEL ${ }^{1}$, Burak DEVECI ${ }^{4}$, \\ Ihsan KARADOGAN ${ }^{4}$, Levent UNDAR ${ }^{1}$ \\ ${ }^{1}$ Akdeniz University Faculty of Medicine, Department of Hematology, Antalya \\ ${ }^{2}$ Marmara University Faculty of Medicine, Department of Hematology, Istanbul \\ ${ }^{3}$ Akdeniz University Faculty of Medicine, Department of Medical Oncology, Antalya \\ ${ }^{4}$ Medstar Antalya Hospital, Department of Hematology, Antalya, TURKEY
}

\begin{abstract}
Platinum- or ifosfamide-based salvage therapies such as DHAP, ICE and ESHAP are frequently used regimens in relapsed/refractory lymphomas. The most important adverse effect of salvage therapies is hematologic toxicity. The aim of this study to compare the hematologic and non-hematological toxicity profiles of two different platinum-based salvage chemotherapy regimens used in relapsed/ refractory lymphoma. We evaluated 51 patients with $\mathrm{HL}$ and $\mathrm{NHL}$ who were treated with DHAP and ESHAP regimens ( $\mathrm{n}=18$ for DHAP and $n=33$ for ESHAP) between January 2000 and July 2010. These patients had received a total of 153 cycles (62 DHAP and 91 ESHAP). Data were retrospectively collected from patients' chart records and electronic patient inventory. Receiving DHAP regimen was found to be an independent risk factor for renal toxicity (Odds ratio $[\mathrm{OR}]=23.6, p=0.03$ ) and independent predictor of platelet transfusion requirement (OR: 7.55, $\mathrm{p}=0.03)$. Overall response was significantly higher in DHAP group $(86.7 \%$ vs $48.3 \%, p=$ 0.03 ) but there was no significant difference between two groups in terms of median survival. DHAP regimen is associated with higher response rates but has no survival advantage. Although the hematologic and non-hematologic toxicity profiles were similar, increased risk for renal toxicity and platelet transfusion requirement should be considered for patients planned to receive DHAP regimen.
\end{abstract}

Keywords: Lymphoma, Salvage chemotherapy, Toxicity

\section{ÖZET}

Relaps/Refrakter Lenfomalı Olgularda ESHAP ve DHAP Kurtarma Rejimlerinin Toksisite Açısından Retrospektif Analizi

Günümüzde relaps/refrakter lenfomalı olgularda sık kullanılan kurtarma kemoterapi rejimleri arasında ESHAP, ICE, DHAP gibi platin temelli ve ifosfamid temelli rejimler yer almaktadır. Kurtarma rejimlerinin en önemli yan etkileri hematolojik toksisiteleridir. Relaps/refrakter lenfomalı olgularda sık kullanılan farklı iki platin temelli kemoterapi rejimini hematolojik ve hematolojik olmayan toksisiteler açısından incelemek amaçlanmıştır. Ocak 2000 ile Temmuz 2010 tarihleri arasında HL ve NHL tanısı ile kurtarma kemoterapisi olarak DHAP ve ESHAP uygulanan 51 hasta (33 ESHAP, 18 DHAP) değerlendirildi. Bu hastalara toplam 153 siklus (91 siklus ESHAP, 62 siklus DHAP) kurtarma kemoterapisi uygulandı. Hematoloji Bilim Dalı kayıtları, hastane arşivi ve elektronik hasta dosya sistemi kullanılarak retrospektif inceleme yapıldı. DHAP uygulanmış olmak renal toksisite gelişimi $(\mathrm{OR}=23.6, p=0.03)$ ve trombosit transfüzyonu gereksinimi (OR: 7.55, $p=0.03$ ) açıından bağımsız bir risk faktörü saptandı. Genel yanıt oranı DHAP grubunda anlamlı olarak daha yüksek iken (\%86.7 ve \%48.3, p= 0.03) ortanca sağkalım açısından iki grup arasında anlamlı bir fark saptanmadı. DHAP rejiminde yanıt oranları yüksek olmasına rağmen sağkalım avantajının olmadığı gözlenmiştir. Hematolojik ve hematolojik olmayan toksisite profili benzer olmasına rağmen özellikle trombosit transfüzyonu gereksinimi ve potansiyel renal toksisite DHAP uygulanması planlanan hastalarda göz önünde bulundurulmalıdır.

Anahtar Kelimeler: Lenfoma, Kurtarma kemoterapi, Toksisite 


\section{INTRODUCTION}

Despite recent advances in lymphoma therapy, 20 to $30 \%$ of patients with lymphoma need salvage chemotherapy (SC) for refractory/relapsed disease. With conventional treatment modalities, most patients who fail to respond to front-line therapy or who relapse from complete response (CR) still carry an unfavorable prognosis. ${ }^{1,2}$ Patients who relapse after anthracycline-based chemotherapy may be eligible for aggressive second-line chemotherapies and autologous stem cell transplantation (ASCT) if their lymphoma is chemosensitive. ${ }^{3}$ Only patients younger than 70 years old can benefit from ASCT in situation of relapse. A number of SC regimens have been proposed to achieve an optimum cytoreduction before ASCT and to improve the outcome in relapsed/refractory setting. Most of these regimens are either cytarabine/platinum- or ifosfamide-based..$^{4-7}$ Most commonly used SC regimens including DHAP (dexamethasone, high-dose cytarabine, and cisplatin), ESHAP (etoposide, methylprednisolone, high-dose cytarabine, and cisplatin), IIVP (ifosfamide, idarubicin, and etoposide), and ICE (ifosfamide, carboplatin, and etoposide) with or without rituximab (R) can lead to a complete (CR) and overall response rate (ORR) of $10-60 \%$ and $40-80 \%$, respectively. ${ }^{1,4-7}$

Although comparable efficacy have been reported in various non-comparative studies, optimal SC regimen for those patients remains to be elucidated. Therefore, efforts to identify the best pre-transplant SC regimen, combining therapeutic activity, stem cell mobilizing potential, and low toxicity, represent a challenging issue for these patients. ${ }^{1,8}$ In 1988, Velasquez et al. reported the preliminary results of a combination regimen DHAP as the salvage therapy for refractory/relapsed non-Hodgkin's lymphoma (NHL). ${ }^{4}$ In a second study reported in 1994, the authors added etoposide to DHAP to form a new regimen ESHAP. The dose of cytarabine in the ESHAP regimen was reduced in order to incorporate etoposide into the regimen safely. ${ }^{5}$ The CORAL study, that is the phase III comparison of salvage regimens, showed no difference in terms of response rate, transplantation rate, or progression-free survival between R-DHAP and R-ICE. ${ }^{9}$ However, those salvage regimens are associated with significant grade $3 / 4$ hematologic, and to a lesser degree (typically grade $1 / 2$ ) of non-hematologic toxicity. Grade 3/4 neutropenia occurs in $50 \%$ to $70 \%$ of patients. Grade 3/4 thrombocytopenia is observed in $30 \%$ to $90 \%$. Between $40 \%$ and $70 \%$ of patients need at least one unit of red blood cell transfusions during or after the chemotherapy (10). Recently Crump and colleagues reported on an international phase III trial comparing DHAP with gemcitabine, dexamethasone, and cisplatin (GDP). ${ }^{11}$ This trial showed no difference regarding efficacy, but less toxicity with the GDP. Since several salvage regimens are available for patients with relaps/refractory lymphoma but none is clearly superior to each other. So the choice of secondline chemotherapy must be guided by the efficacy and toxicity profiles reported in single-arm studies and retrospective analyses. In this study, our aim was to compare the efficacy and toxicity profiles of the two platinum-based salvage regimens, DHAP and ESHAP, for the treatment of relapsed/ refractory lymphoma.

\section{PATIENTS AND METHODS}

\section{Study Design and Patients}

This retrospective study was conducted at the Akdeniz University Hospital, Antalya, Turkey. The study protocol was reviewed and approved by the local ethics committee, in accordance with the ethical principles for human investigations, as outlined by the Second Declaration of Helsinki. Between January 2000 to July 2010, 51 patients with refractory/relapsed Hodgkin lymphoma or NHL who were planned to receive DHAP $(\mathrm{n}=18)$ or ESHAP $(n=33)$ regimens were included into the study.

Data were obtained from patients' chart records and electronic patient inventory. Details of patient characteristics, number of prior chemotherapy regimens, disease status prior to salvage chemotherapy, response and toxicity profile of salvage regimens, and response rates were obtained. All NHL patients were treated with CHOP (cyclophosphamide, doxorubicin, vincristine, and prednisolone) regimen with or without rituximab prior to SC. Patients with HL received ABVD (doxorubicin, bleomycin, vinblastine and dacarbazine). For staging and restaging purposes, the patients' files were reviewed for physical examination, chest X-ray, 
computed and positron emission tomography, bone marrow aspirate and biopsy, if performed.

\section{Definitions}

Lymphoma classification was performed in accordance with the World Health Organization (WHO) classification. ${ }^{12}$ Ann Arbor staging system was used for clinical staging in all cases. ${ }^{13}$ Primary refractory disease was defined as failure to achieve $\mathrm{CR}$ with a front-line regimen or achievement of $\mathrm{CR}$, which lasts less than three months or progression during the front-line treatment. ${ }^{14}$ The response duration was defined as the time elapsed between the date of the confirmed response and progression. Response to therapy was assessed by physical examination of all palpable lymph node regions (before each course) and computed tomography scans of the involved sites as recommended in the International Working Group Criteria, 1999. ${ }^{15}$ The response assessment after SC was evaluated after two cycles. Administration of additional SC cycles was at the discretion of the treating physician. The $\mathrm{CR}$ was defined as the disappearance of all clinical and radiographic evidence of disease for at least one month. Partial response (PR) was defined as a greater than $50 \%$ reduction in the largest diameter of measurable disease lasting more than a month. Any response less than PR were considered as treatment failure. Early relapse was defined as a CR lasting for $\geq 3$ months but less than 12 months. Relapses those occur beyond 12 months were described as late relapse. Overall survival was measured from the time of relapse until death of any cause or last contact. Progression-free survival was estimated from the time of relapse until death of any cause, progression or last contact. ${ }^{16}$

\section{Salvage Therapy}

The inpatient DHAP regimen was as follows: cisplatin $100 \mathrm{mg} / \mathrm{m}^{2}$ was infused over 24 hours on day 1 , cytosine arabinoside (ara-C) $2 \mathrm{~g} / \mathrm{m}^{2}$ in 3 hours i.v. twice a day on day 2 , and dexamethasone 40 mg given i.v. on days 1 to 4, every 21 to 28 days. Outpatient DHAP regimen included cisplatin 100 $\mathrm{mg} / \mathrm{m}^{2}$ which was infused over 6 hours on day 1 , ara-C $2 \mathrm{~g} / \mathrm{m}^{2}$ in 3 hours i.v. on day 2 to 3 , and dexamethasone $40 \mathrm{mg}$ given i.v. on days 1 to 4 , every
21 to 28 days. The ESHAP regimen consisted of etoposide (40 mg/m², days 1-4), methylprednisolone (500 $\mathrm{mg}$, days $1-4)$, ara-C (2 $\mathrm{g} / \mathrm{m}^{2}$, day 5$)$, and cisplatin $\left(25 \mathrm{mg} / \mathrm{m}^{2}\right.$, days $\left.1-4\right)$, every 21 to 28 days, using its original schedule with dose modifications. ESHAP regimen was administered in inpatient setting only. Rituximab $375 \mathrm{mg} / \mathrm{m}^{2}$ was added if CD20 was positive. Granulocyte colonystimulating factor was given between the cycles to all patients for primary prophylaxis against febrile neutropenia or for stem cell mobilization.

\section{Assessment of Toxicity}

Toxicity was assessed on every cycle. Toxic effects were originally graded according to the National Cancer Center Institute Common Toxicity Criteria (version 2.0). ${ }^{17}$

\section{Statistical Analysis}

Shapiro-Wilk test was used to test the normality of data distribution. The data were expressed as arithmetic median, minimum, maximum, means and standard deviations. The chi-square test or Fisher Exact test was used to compare the categorical variables between the groups. Independent samples T-test and Mann-Whitney U tests were used for the comparison of the continuous variables, where appropriate. Simple logistic regression analysis was used to evaluate the effects of the treatment response and toxicity. Survival curves were constructed using the method of Kaplan and Meier. Differences in survival between individual patient groups were analyzed using the generalized logrank test. A two-sided $\mathrm{p}$ value $<0.05$ was considered to be statistically significant.

\section{RESULTS}

\section{Patient Demographics}

Data of a total of 51 patients were included in the analyses. Eighteen patients were received DHAP. ESHAP were given to a total of 33 patients. Median age was 46 years for DHAP and 42 years for ESHAP groups $(\mathrm{p}=0.50)$. The histopathological subtypes of the patients with NHL were diffuse large B-cell lymphoma $(n=10 ; 47 \%)$, marginal zone lymphoma $(n=1 ; 5 \%)$, follicular lymphoma 
Table 1. Demographical and clinical features of the groups

\begin{tabular}{|c|c|c|c|}
\hline Variables & DHAP $(n=18)$ & ESHAP $(n=33)$ & $\mathbf{P}$ \\
\hline Age, years, median (range) & $46(22-69)$ & $42(20-69)$ & 0.50 \\
\hline Gender, female-to-male & $6 / 12$ & $15 / 18$ & 0.60 \\
\hline Diagnosis, HL/NHL & $14 / 4$ & $16 / 17$ & 0.08 \\
\hline Advance stage disease, $\mathrm{n}(\%)$ & $9(50)$ & $17(53)$ & 1.00 \\
\hline Presence of B symptoms, n (\%) & $8(50)$ & $13(46)$ & 1.00 \\
\hline Bone marrow involvement, $\mathrm{n}(\%)$ & $3(17)$ & $7(23)$ & 0.70 \\
\hline IPI score $\geq 3, \mathrm{n}(\%)$ & $2 / 3(67)$ & $7 / 14(50)$ & 1.00 \\
\hline IPS score $\geq 3, \mathrm{n}(\%)$ & $4 / 14(29)$ & $5 / 12(42)$ & 0.70 \\
\hline Primary refractory/early relapsed disease, n (\%) & $5 / 17(29)$ & 23/33 (70) & 0.02 \\
\hline Hospitalization duration, days, median (range) & $8.3(4-21)$ & $12.5(6.0-19.5)$ & 0.08 \\
\hline Previous rituximab, n (\%) & $2 / 4(50)$ & $4 / 15(27)$ & 0.60 \\
\hline Previous radiotherapy, n (\%) & $6(18)$ & $3(17)$ & 1.00 \\
\hline First-line ABVD treatment cycles, median (range) & $6(4-8)$ & $6(1-8)$ & 0.80 \\
\hline ABVD treatment $\geq 6, \mathrm{n}(\%)$ & $10 / 14(71)$ & $14 / 18(78)$ & 0.70 \\
\hline First-line R-CHOP cycles, median (range) & $6(6-8)$ & $6(6-8)$ & 0.60 \\
\hline Salvage treatment cycles, median (range) & $3(2-6)$ & $2(1-6)$ & 0.03 \\
\hline Salvage treatment cycles $\geq 3, \mathrm{n}(\%)$ & $14 / 18(78)$ & $16 / 33(48)$ & 0.07 \\
\hline
\end{tabular}

$(\mathrm{n}=2 ; 9.5 \%)$, angioimmunoblastic T-cell lymphoma $(\mathrm{n}=1 ; 5 \%)$, anaplastic large cell lymphoma $(\mathrm{n}=2 ; 9.5 \%)$, subcutaneous panniculitis-like T-cell lymphoma $(\mathrm{n}=1 ; 5 \%)$, T-cell rich B-cell lymphoma $(n=1 ; 5 \%)$, and unclassified types $(n=3 ; 14 \%)$. The histopathological subtypes of the patients with HL were that: nodular sclerosing $(n=19 ; 63 \%)$, mixt cellular $(n=3 ; 10 \%)$, lymphocyte rich $(n=$ $1 ; 3 \%)$, lymphocyte depleted $(n=1 ; 3 \%)$ and unclassified classical HL $(n=6 ; 20 \%)$. ESHAP group consisted more patients with primary refractory or early relapsed disease ( $70 \%$ vs $29 \%, \mathrm{p}=0.02)$. Patients who received DHAP had more treatment cycles ( 3 vs 2 cycles, $p=0.03$ ). NHL had a trend to be more frequent in ESHAP group (51.5\% vs $22.2 \%$, $\mathrm{p}=0.08$ ). As expected, patients who received ESHAP had a tendency to have more hospital stay (12.5 vs 8.3 days, $\mathrm{p}=0.08$, Table 1 ).

\section{Adverse Events}

The main toxicity of the salvage regimens was he- matological adverse events. Hematologic toxicity did not differ between the groups except that the patients who received DHAP required more platelet transfusions during the treatment cycles ( 3 vs 1 platelet apheresis per cycle, $\mathrm{p}=0.03$, Table 2). When the diagnosis, the remission status before the $\mathrm{SC}$, the number of salvage treatment cycles, and the salvage regimen included into the simple logistic regression analysis, DHAP regimen retained as an independent predictor of platelet transfusion requirement (Odds ratio [OR]: 7.55; 95\% confidential interval [CI]: 1.21 to $47.13, \mathrm{p}=0.03$ ).

Acute renal failure was observed more frequently in DHAP group in univariate analysis (44\% vs $12 \%, \mathrm{p}=0.02$; Table 2). Receiving DHAP regimen was an independent risk factor for acute renal failure in simple logistic regression analysis (OR: 30.69 ; $95 \%$ CI: 2.29 to $411.38, \mathrm{p}=0.01$ ).

In a total of 15 cycles, 11 (21.5\%) patients experienced febrile neutropenia. Patients who received DHAP had a tendency to have more febrile neutro- 


\begin{tabular}{|c|c|c|c|}
\hline Variables & DHAP $(n=18)$ & ESHAP $(n=33)$ & $\mathbf{P}$ \\
\hline \multicolumn{4}{|l|}{ Hematologic, grade III/IV } \\
\hline Anemia, n (\%) & $10(56)$ & $24(73)$ & 0.20 \\
\hline Neutropenia, n (\%) & $12(67)$ & $18(55)$ & 0.60 \\
\hline Thrombocytopenia, n (\%) & $13(72)$ & $20(61)$ & 0.60 \\
\hline Red blood cell transfusions, median (range) & $4(0-10)$ & $2(0-19)$ & 0.50 \\
\hline Platelet transfusions, median (range) & $3(0-9)$ & $1(0-8)$ & 0.03 \\
\hline$\geq 3$ apheresis transfusion per cycle, $\mathrm{n}(\%)$ & $11(61.1)$ & $9(27.3)$ & 0.02 \\
\hline \multicolumn{4}{|l|}{ Non-hematologic } \\
\hline Acute renal failure, $\mathrm{n}(\%)$ & $8 / 18(44)$ & 4/33 (12) & 0.02 \\
\hline Antifungal treatment, n (\%) & 2/18 (11) & $1 / 33(3)$ & 0.30 \\
\hline Febrile neutropenia attacks, median (range) & $0(0-3)$ & $0(0-1)$ & 0.09 \\
\hline Treatment delay due to toxicity, median (range) & $0(0-1)$ & $0(0-1)$ & 0.03 \\
\hline
\end{tabular}

penia episodes ( $p=0.09$, Table 2$)$. Simple logistic regression analysis revealed that DHAP regimen is associated with higher risk of febrile neutropenia (OR: 6.51 ; 95\% CI: 1.15 to $36.72, \mathrm{p}=0.03$ ).

None of the patients died due to the treatment-related toxicity. Treatment delay due to the toxicity was observed in five patients in DHAP group, and five in ESHAP group. In four patients, treatment was delayed due to renal toxicity. The treatment was postponed in one patient because of febrile neutropenia in DHAP group. All treatment delays were due to infections in patients who received ESHAP. DHAP regimen had a trend to be associated with treatment delays in simple logistic regression analysis (OR: 8.13; 95\% CI: 0.84 to 78.46 , $\mathrm{p}=0.07)$.

\section{Efficacy}

The complete and overall response rates were significantly higher in DHAP group $(\mathrm{p}=0.045, \mathrm{p}=0.03$ respectively). On the other hand, stable or progressive disease was more frequent following ESHAP (Table 3). DHAP was associated with higher overall response after simple logistic regression analysis (OR: 6.26; 95\% CI: 1.13 to $34.83, \mathrm{p}=0.04$ ).
According to univariate analysis, higher number of stem cells was collected by ESHAP (11.69 $(0-33.50)$ vs $6.42(0-19.54), \mathrm{p}=0.008$, Table 3$)$. However, logistic regression analysis revealed that DHAP and ESHAP had similar effect on the quantity of stem cells collected (OR: 2.03 ; $95 \%$ CI: 0.42 to $9.94, \mathrm{p}=0.38$ ).

Median follow-up was 20 months. Median and overall survival at 2-years was comparable between DHAP and ESHAP groups (Table 3, Figure $1)$.

\section{DISCUSSION}

Our study is the first study in literature mainly compares the toxicity and gives some information's about the efficacy of two platinum-based lymphoma salvage regimens, DHAP and ESHAP, with or without rituximab for patients suffering from relapsed HL and heterogeneous histologic subtypes of NHL. The main findings of the study were that; (i) DHAP regimen was an independent predictor of platelet transfusion requirement; (ii) receiving DHAP regimen was found to be an independent risk factor for renal toxicity; (iii) febrile neutropenia were observed more frequently in DHAP group; (iv) overall response was higher in DHAP group; (v) median survival was similar both 


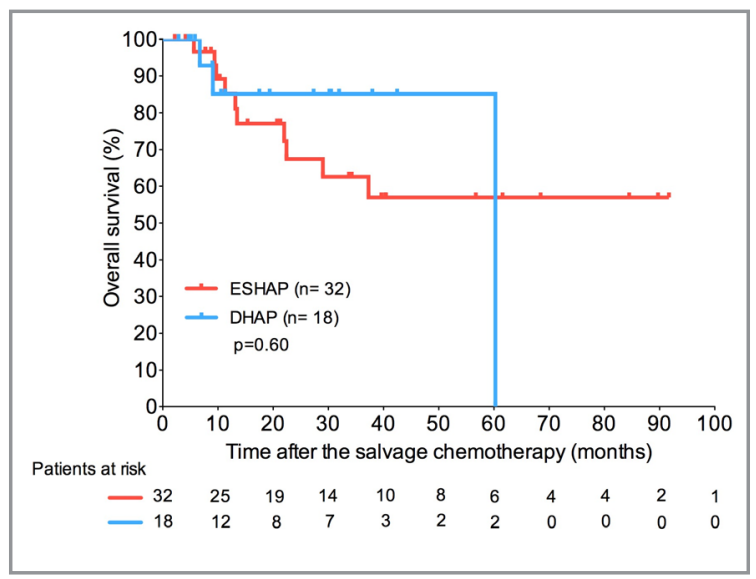

Figure 1. Overall survival in patients who received DHAP and ESHAP for relapsed refractory lymphoma.

in two regimens; and (vi) both regimens had similar effect on the quantity of stem cells collected.

In literature, several studies investigated the hematologic and non-hematologic toxicities of the salvage regimens in patients with relapsed or refractory HL and NHLs. While these regimens had been found to be effective, they had different toxicity profiles, and unfortunately prospective randomized studies comparing these regimens are lacking. ${ }^{1}$ Mey et al. revealed acceptable limits of toxicity with DHAP regimen with or without rituximab in their study. They observed a higher rate of hematologic toxicities with more patients developing WHO grade 3 and 4 granulocytopenia and thrombocytopenia in the combined treatment group. ${ }^{18}$ Abal1 et al. compared the toxicity profiles of both ICE and DHAP regimens in the treatment of patients with relapsed/refractory HL or NHL, and found that the toxicity profiles of both regimens were similar. The major toxicities were hematological in both groups including grade- 3 and -4 granulocytopenia and thrombocytopenia. The patients required similar platelet and red blood cell transfusions, and reversible elevations of serum creatinine were observed in both groups. ${ }^{1}$ Philip et al. observed grade- 3 thrombocytopenia in $34 \%$ of 50 patients treated with the DHAP regimen without rituximab, and another study performed by Mey et al. reported that the need for platelet transfusions in $30.2 \%$ and febrile neutropenia occurred in only $5.7 \%$ of patients in their study. ${ }^{19,20}$ Recently Crump reported that GDP regimen was associated with less toxicity and hospitalization, and fewer platelet transfusion requirements $(31 \% \mathrm{v} 47 \%$; $\mathrm{p}<0.001)$ than DHAP regimen. ${ }^{11}$ In our study DHAP is associated with higher response rates, but also with increased platelet transfusions and kidney injuries. Renal toxicity may be related to administiration of DHAP as an outpatient setting without adequate hydration in some patients. Also patients treated by DHAP received more cycles of chemotherapy than those treated by ESHAP. This can be explained with DHAP is more dose-dense than ESHAP. It is therefore maybe not surprising that DHAP is associated with more toxicity.

Table 3. Response of relapsed or refractory lymphoma patients to salvage chemotherapy regimens

\begin{tabular}{|c|c|c|c|}
\hline Variables & DHAP & ESHAP & $\mathbf{P}$ \\
\hline \multicolumn{4}{|l|}{ Response $^{a}$} \\
\hline Overall response, n (\%) & $13 / 15(86.7)$ & 14/29 (48.3) & 0.030 \\
\hline Complete response, $\mathrm{n}(\%)$ & 8/15 (53.3) & $8 / 29(27.6)$ & 0.045 \\
\hline Partial response, n (\%) & $5 / 15(33.3)$ & $6 / 29(20.7)$ & 0.360 \\
\hline Stable/progressive disease, n (\%) & 2/15 (13.3) & $15 / 29(51.7)$ & 0.020 \\
\hline \multicolumn{4}{|l|}{ Mobilization, median (range) } \\
\hline CD34 (x106/kg) & $6.42(0-19.54)$ & $11.69(0-33.50)$ & 0.008 \\
\hline \multicolumn{4}{|l|}{ Survival ${ }^{\mathrm{b}}$} \\
\hline Median, months & 60 & Not reached & 0.600 \\
\hline 2-year survival (\%) & 85.1 & 67.4 & 0.600 \\
\hline
\end{tabular}


On the other hand, it has been reported that the major complication of ESHAP was myelosuppression as well. Wang et al. performed a trial investigating clinical efficacy and adverse effects of ESHAP regimen in relapsed/refractory lymphoma and revealed that all patients experienced grade- 4 leukopenia and thrombocytopenia. ${ }^{21}$ Choi et al. reported that the major toxicities were neutropenia and thrombocytopenia and two patients died of sepsis associated with neutropenia. ${ }^{22}$ Labrador et al. observed that grade $\geq 3$ hematological toxicity was reduced to $41 \%$ of patients, and only $10 \%$ had grade- 4 neutropenia ( $7 \%$ febrile neutropenia), with no toxic deaths. ${ }^{23}$ However, in a previous study Aparicio et al. investigated 22 patients with refractory/relapsing Hodgkin's lymphoma, grade 3-4 hematological toxicity was seen in approximately $60 \%$ of patients, and three patients (13\%) died of toxic effects of ESHAP, which would be unacceptable. ${ }^{24}$ In our study, hematologic toxicity including grade 3-4 anemia (56\%), neutropenia (67\%), and thrombocytopenia (72\%) were seen in DHAP group; and $73 \%, 55 \%$, and $61 \%$ respectively in ESHAP group.

Non-hematological toxicities of the salvage regimens include stomatitis, dermatitis, impaired liver and renal functions, cardiac toxicity, neurotoxicity, cerebellar toxicity and chemical conjunctivitis..$^{10,21}$ It has been reported that DHAP and ESHAP are associated with irreversible increase in serum creatinine in $4-8 \%$ of patients. ${ }^{25}$ Press et al. reported nephrotoxicity in nearly $20 \%$ of the patients receiving DHAP and in two patients' therapy was discontinued because of severe renal side effects. ${ }^{26}$ Witzig et al. used salvage chemotherapy using RDHAP and observed five events of nephrotoxicity occurred in $7 \%(4 / 57)$ of patients - four patients had grade- 3 creatinine, and one patient had grade- 4 renal failure with the overdose of cytosine arabinoside administrating, and died on study during cycle $2 .{ }^{27}$ In our study, reversible renal toxicity was seen $44 \%$ in DHAP and 12\% in ESHAP group, and the other main toxicities were not seen both in the treatment groups.

The optimum salvage regimen for relapsed/refractory HL and NHLs has not yet been defined, and the treatment outcomes are still not satisfactory. ${ }^{1,2}$ The comparison of both DHAP and ESHAP treatments in literature is limited, only one study exists in literature ${ }^{28}$, and the survival rates of the DHAP and ESHAP treatments vary in different studies. In the Parma trial the ORR to DHAP was $58 \%$, and the other largest trial of DHAP included 204 patients and found an ORR of 59\% (120/204) with a $25 \%(51 / 204)$ CR rate. ${ }^{3,29}$ Velasquez et al. reported ESHAP survival rates of an ORR of $67 \%$ with $37 \%$ $\mathrm{CR}$ in 122 patients with a variety of NHL disease types. ${ }^{5}$ In literature only Rodriguez et al. compared the treatment outcomes of DHAP and ESHAP regimens in the same study. The authors reported that ESHAP regimen is associated with a longer survival and time-to-treatment failure compared with DHAP, but ESHAP is not found to be associated with a cured fraction of $>10 \%$ than DHAP regimen. ${ }^{28}$ Although in our study HL, B-cell and T-cell lymphomas were not analyzed separately, in overall the complete and total response was significantly higher in DHAP group compared to ESHAP group. In addition, the 20 months survival for all patients was found $85.1 \%$ for DHAP and $67.4 \%$ for ESHAP group, the complete remission rate and median survival was found to be similar both in two regimens.

In conclusion, both two regimens were feasible, effective and have acceptable side effects in the treatment of relapse/refractory lymphomas. DHAP regimen is associated with higher response rates but has no survival advantage. Although the hematologic and non-hematologic toxicity profiles were similar, increased risk for renal toxicity and platelet transfusion requirement should be considered for patients planned to receive DHAP regimen. The design of our study was a retrospective single center experience, the sample size was relatively small and the population was very heterogeneous regarding histologic subtypes of NHL. Therefore, randomized prospective multicenter studies with a larger sample size including more homogeneous histologic subtypes of lymphomas are needed for this issue.

\section{REFERENCES}

1. Abali H, Urün $Y$, Oksüzoglu B, et al. Comparison of ICE (ifosfamide-carboplatin-etoposide) versus DHAP (cytosine arabinoside-cisplatin-dexamethasone) as salvage chemotherapy in patients with relapsed or refractory lymphoma. Cancer Invest 26: 401-406, 2008. 
2. Shea TC, Beaven AW, Moore DT, et al. Sequential high-dose ifosfamide, carboplatin and etoposide with rituximab for relapsed Hodgkin and large B-cell non-Hodgkin lymphoma: increased toxicity without improvement in progression-free survival. Leuk Lymphoma 50: 741-8, 2009.

3. Philip T, Guglielmi C, Hagenbeek A, et al. Autologous bone marrow transplantation as compared with salvage chemotherapy in relapses of chemotherapy-sensitive non-Hodgkin's lymphoma. N Engl J Med 333: 1540-1545, 1995.

4. Velasquez WS, Cabanillas F, Salvador P, et al. Effective salvage therapy for lymphoma with cisplatin in combination with high-dose Ara-C and dexamethasone (DHAP). Blood 71: 11722, 1988

5. Velasquez WS, McLaughlin P, Tucker S, et al. ESHAP--an effective chemotherapy regimen in refractory and relapsing lymphoma: a 4-year follow-up study. J Clin Oncol 12: 1169-1167, 1994.

6. Jerkeman M, Leppä S, Kvaløy S, Holte H. ICE (ifosfamide, carboplatin, etoposide) as second-line chemotherapy in relapsed or primary progressive aggressive lymphoma--the Nordic Lymphoma Group experience. Eur J Haematol 73: 179-182, 2004.

7. Salar A, Martino R, Perea G, et al. High-dose infusional ifosfamide, etoposide plus methylprednisolone followed by dexamethasone, high-dose ara- $\mathrm{C}$ and cisplatinum and autologous stem cell transplantation for refractory or relapsed aggressive non-Hodgkin's lymphoma. Haematologica 87: 1028-1035, 2002.

8. Fernández de Larrea C, Martínez C, Gaya A, et al. Salvage chemotherapy with alternating MINE-ESHAP regimen in relapsed or refractory Hodgkin's lymphoma followed by autologous stem-cell transplantation. Ann Oncol 21: 1211-1216, 2010.

9. Gisselbrecht C, Glass B, Mounier N, et al. Salvage regimens with autologous transplantation for relapsed large B-cell lymphoma in the rituximab era. J Clin Oncol 28: 4184-4190, 2010.

10. Hernandez-llizaliturri FJ, Czuczman MS. Therapeutic options in relapsed or refractory diffuse large B-cell lymphoma. Part 1. Current treatment approaches. Oncology (Williston Park) 23: 546-553, 2009.

11. Crump M, Kuruvilla J, Couban S, et al. Randomized comparison of gemcitabine, dexamethasone, and cisplatin versus dexamethasone, cytarabine, and cisplatin chemotherapy before autologous stem-cell transplantation for relapsed and refractory aggressive lymphomas: NCIC-CTG LY.12. J Clin Oncol 32: 3490-3496, 2014

12. Harris NL, Jaffe ES, Diebold J, et al. The World Health Organization classification of neoplastic diseases of the hematopoietic and lymphoid tissues. Report of the Clinical Advisory Committee meeting, Airlie House, Virginia, November, 1997. Ann Oncol 10: 1419-1432, 1999.

13. Lister TA, Crowther D, Sutcliffe SB, et al. Report of a committee convened to discuss the evaluation and staging of patients with Hodgkin's disease: Cotswolds meeting. J Clin Oncol. 1989; 7: 1630-1636. Erratum in: J Clin Oncol 8: 1602, 1990.
14. Josting A, Reiser M, Rueffer $U$, et al. Treatment of primary progressive Hodgkin's and aggressive non-Hodgkin's lymphoma: is there a chance for cure? J Clin Oncol 18: 332-339, 2000.

15. Cheson BD, Horning SJ, Coiffier B, et al. Report of an international workshop to standardize response criteria for nonHodgkin's lymphomas. NCl Sponsored International Working Group. J Clin Oncol. 1999; 17(4): 1244. Review. Erratum in: J Clin Oncol 18: 2351-2352, 2000.

16. Cabanillas F, Hagemeister FB, McLaughlin P, et al. Results of MIME salvage regimen for recurrent or refractory lymphoma. J Clin Oncol 5: 407-412, 1987.

17. Common Toxicity Criteria, Version 2.0 (CTC, v2.0). Cancer Therapy Evaluation Program. National Cancer Institute 1999; http://www.eortc.be/services/doc/ctc/ctcv20_4-30992.pdf. Access date: November 15, 2015.

18. Mey UJ, Olivieri A, Orlopp KS, et al. DHAP in combination with rituximab vs DHAP alone as salvage treatment for patients with relapsed or refractory diffuse large B-cell lymphoma: a matched-pair analysis. Leuk Lymphoma 47: 2558-2566, 2006.

19. Philip T, Chauvin F, Armitage J, et al. Parma international protocol: pilot study of DHAP followed by involved-field radiotherapy and BEAC with autologous bone marrow transplantation. Blood 77: 1587-1592, 1991.

20. Mey UJ, Orlopp KS, Flieger D, et al. Dexamethasone, highdose cytarabine, and cisplatin in combination with rituximab as salvage treatment for patients with relapsed or refractory aggressive non-Hodgkin's lymphoma. Cancer Invest 24: 593600, 2006.

21. Wang WS, Chiou TJ, Liu JH, et al. ESHAP as salvage therapy for refractory non-Hodgkin's lymphoma: Taiwan experience. Jpn J Clin Oncol 29: 33-37, 1999.

22. Choi CW, Paek CW, Seo JH, et al. ESHAP salvage therapy for relapsed or refractory non-Hodgkin's lymphoma. J Korean Med Sci 17: 621-624, 2002.

23. Labrador J, Cabrero-Calvo M, Pérez-López E, et al. ESHAP as salvage therapy for relapsed or refractory Hodgkin's lymphoma. Ann Hematol 93: 1745-1753, 2014.

24. Aparicio J, Segura A, Garcerá S, et al. ESHAP is an active regimen for relapsing Hodgkin's disease. Ann Oncol 10: 593-595, 1999.

25. Oki Y, Ogura M, Kato H, Kikuchi A, et al. Phase II study of a salvage regimen using cyclophosphamide, high-dose cytarabine, dexamethasone, etoposide, and rituximab in patients with relapsed or refractory B-cell non-Hodgkin's lymphoma. Cancer Sci 99: 179-184, 2008.

26. Press OW, Livingston R, Mortimer J, et al. Treatment of relapsed non-Hodgkin's lymphomas with dexamethasone, highdose cytarabine, and cisplatin before marrow transplantation. J Clin Oncol 9: 423-431, 1991.

27. Witzig TE, Geyer SM, Kurtin PJ, et al. North Central Cancer Treatment Group. Salvage chemotherapy with rituximab DHAP for relapsed non-Hodgkin lymphoma: a phase II trial in the North Central Cancer Treatment Group. Leuk Lymphoma 49: 1074-1080, 2008. 
28. Rodriguez-Monge EJ, Cabanillas F. Long-term follow-up of platinum-based lymphoma salvage regimens. The M.D. Anderson Cancer Center experience. Hematol Oncol Clin North Am11: 937-947, 1997.

29. Blay J, Gomez F, Sebban C, et al. The International Prognostic Index correlates to survival in patients with aggressive lymphoma in relapse: analysis of the PARMA trial. Parma Group. Blood 92: 3562-3568, 1998.

\section{Correspondence}

Dr. Ozan SALIM

Akdeniz Üniversitesi Tıp Fakültesi

Hematoloji Bilim Dalı

07058 Konyaaytı

ANTALYA / TURKEY

Tel: (+90-533) 4243625

email: ozansalim@gmail.com 